\title{
The seed coat of Phaseolus vulgaris interferes with the development of the cowpea weevil [Callosobruchus maculatus (F.) (Coleoptera: Bruchidae)]
}

\author{
LUCIANA B. SILVA ${ }^{1}$, MAURÍCIO P. SALES ${ }^{2}$, ANTÔNIA E.A. OLIVEIRA ${ }^{1}$, \\ OLGA L.T. MACHADO ${ }^{1}$, KÁTIA V.S. FERNANDES ${ }^{1}$ and JOSÉ XAVIER-FILHO ${ }^{1}$ \\ ${ }^{1}$ Laboratório de Química e Função de Proteínas e Peptídeos, Centro de Biociências e Biotecnologia, \\ Universidade Estadual do Norte Fluminense, 28015-620 Campos dos Goytacazes, RJ, Brasil \\ ${ }^{2}$ Departamento de Bioquímica, Universidade Federal do Rio Grande do Norte, 59072-970 Natal, RN, Brasil \\ Manuscript received on August 21, 2003; accepted for publication on October 1, 2003; \\ contributed by JosÉ XAVIER-FILHO*
}

\begin{abstract}
We have confirmed here that the seeds of the common bean (Phaseolus vulgaris, L.) do not support development of the bruchid Callosobruchus maculatus (F.), a pest of cowpea [Vigna unguiculata (L.) Walp] seeds. Analysis of the testa (seed coat) of the bean suggested that neither thickness nor the levels of compounds such as tannic acid, tannins, or HCN are important for the resistance. On the other hand, we have found that phaseolin (vicilin-like 7S storage globulin), detected in the testa by Western blotting and N-terminal amino acid sequencing, is detrimental to the development of $C$. maculatus. As for the case of other previously studied legume seeds (Canavalia ensiformis and Phaseolus lunatus) we suggest that the presence of vicilin-like proteins in the testa of $P$. vulgaris may have had a significant role in the evolutionary adaptation of bruchids to the seeds of leguminous plants.
\end{abstract}

Key words: common bean, phaseolin (vicilin), testa, resistance, cowpea weevil.

\section{INTRODUCTION}

The common bean (P. vulgaris L.) is a widely cultivated, high-protein containing, legume originated in the New World which has been domesticated both in Meso America and South America (Smartt 1990). The common bean seeds are endowed with an array of low and high molecular weight substances that protect them against attack by many herbivores (Smartt 1990). Many proteins like lectins, $\alpha$-amylase inhibitors, arcelins, trypsin inhibitors and others, while protecting the seeds against insects and herbivores in general do not pro-

*Member of Academia Brasileira de Ciências

Correspondence to: José Xavier-Filho

E-mail: xavier@uenf.br tect them against attack by pests, which presumably have co-evolved with the species (Sales et al. 2000). Some of these pests like the weevils Acanthoscelides obtectus Say and Zabrotes subfasciatus Boh. (Coleoptera: Bruchidae) attack the common bean seeds both in the field and in storage causing severe losses to farmers (Schoonhoven et al. 1983). Other bruchids like C. maculatus F., a pest of the seeds of $V$. unguiculata (L.) Walp. (cowpea), do not attack the seeds of $P$. vulgaris (Applebaum et al. 1970). The reason why C. maculatus does not develop in the seeds of the common bean may be explained by their mutual isolation since the bruchid is an Old World species while $P$. vulgaris has its origin in the New World. 
This discrimination may be explained by different mechanisms one of them being possibly the presence of proteins in the testa, which may cause a delay in the development or entail death of young larvae. We have recently suggested that the seeds of the legumes $P$., and $C$. ensiformis which are of New World origin and related to $P$. vulgaris are resistant to attack by $C$. maculatus due to the presence of vicilins (7S storage globulins), in the testa (Oliveira et al. 1999, Moraes et al. 2000).

\section{MATERIALS AND METHODS}

Seeds. Common bean [P. vulgaris, WAF-9 (white testa) and "preto" (black testa) genotypes] seeds were provided by Empresa de Pesquisa Agropecuária do Rio de Janeiro (Campos dos Goytacazes, RJ, Brazil). Seeds of the C. maculatus-susceptible cowpea (V. unguiculata) cultivars EPACE-10 (brown testa) and "fradinho", (white testa) were obtained from Centro de Ciências Agrárias, Universidade Federal do Ceará (Fortaleza, Brazil) and in local markets. C. maculatus-resistant cowpea seeds (IT81D1045, brown testa) were obtained from IITA (International Institute of Tropical Agriculture, Ibadan, Nigeria), Ibadan, Nigeria trough Centro Nacional de Pesquisa do Arroz e Feijão-Embrapa, Goiânia, Brazil. C. maculatus (cowpea weevil) were provided by J.H. Ribeiro dos Santos from Centro de Ciências Agrárias, Universidade Federal do Ceará (Fortaleza, Brazil) and were maintained in culture (28-30 ${ }^{\circ} \mathrm{C}$ and $65-75 \%$ relative humidity). We employed an antibody against cowpea vicilins raised in white rabbits previously prepared by us and an antibody against $P$. vulgaris phaseolin kindly provided by Dr. Maarten Chrispeels (Dept. of Biology, University of California, San Diego, USA).

C. maculatus behavior. Development of C. maculatus on $P$. vulgaris seeds was observed by placing 2-day old females in glass vials containing ten seeds at $28^{\circ} \mathrm{C}, 60 \%$ relative humidity. After 2 days insects were discarded and the numbers of laid and hatched eggs were counted. Seeds were observed daily for any emergence of adults until the experiment was discarded (40 days). Three replicates were run. For each replicate one seed was chosen for counting the holes made in the testa by larvae.

The effects of the various seed and testa meals and fractions thereof on C. maculatus development were assessed through an artificial seed assay (Macedo et al. 1993). Briefly, artificial seeds (400 $\mathrm{mg}$ ) were made of finely ground cowpea seed meal (EPACE-10) mixed with the materials of interest. For testa meals we used concentrations of 1.0, 2.0, 4.0, 8.0 and $16 \%$ and for globulin fractions these were 1.0, 2.0, 4.0 and $8.0 \%$.

Infestation of artificial seeds was accomplished by placing 2-day old female insects in glass vials containing two seeds for 24 hours at $28^{\circ} \mathrm{C}, 60 \%$ relative humidity. Excess laid eggs were removed from the seeds leaving 2-3 eggs per seed. After 20 days (at $28^{\circ} \mathrm{C}, 60 \%$ relative humidity) infested seeds were opened and the weight and number of larvae were counted. Dose-response curves were drawn and the effective doses for $50 \%$ response $\left(\mathrm{ED}_{50}, \%\right)$ and lethal-doses $\left(\mathrm{LD}_{50}, \%\right)$ were calculated. Control seeds were made with the meal of cowpea seeds without additions. All the experiments were run in triplicate and the data shown are the average of these.

Seed protein isolation. Seeds were carefully dissected in order to separate embryonic tissues from the testa. The finely ground meals of testa-free seeds and testa of $P$. vulgaris (WAF-9) were extracted $\left(1: 10\right.$, meal to buffer ratio) for $3 \mathrm{~h}$ at $5^{\circ} \mathrm{C}$, with $50 \mathrm{mM}$ sodium tetra borate buffer, $\mathrm{pH} 8.0$; the resulting slurry was centrifuged at $10000 \times \mathrm{g}$ for $30 \mathrm{~min}$ at $4^{\circ} \mathrm{C}$. The crude extracts obtained were fractionated by ammonium sulfate and the proteins precipitating between 70 and $90 \%$ saturation were collected, dialyzed against water and freeze dried for further analysis.

Finely ground testa tissues from the several seeds utilized were extracted $(1 \mathrm{~g}$ in $20 \mathrm{ml})$ with a solution, which was $7 \mathrm{M}$ urea and $0.1 \%$ acetic acid for $16 \mathrm{~h}$ under continuous stirring, at $5^{\circ} \mathrm{C}$. The suspensions were centrifuged at $10000 \times \mathrm{g}$ for 30 $\min$ at $4^{\circ} \mathrm{C}$. The supernatants were dialyzed against 
water and the samples containing testa proteins were recovered by freeze-drying.

Embryo vicilins (or phaseolin) were purified by chromatography in a Sephacryl S-400 column $(60 \times$ $2.5 \mathrm{~cm}$ ) employing $0.1 \mathrm{M}$ Tris- $\mathrm{HCl}, 0.25 \mathrm{M} \mathrm{NaCl}$, $\mathrm{pH} 8.0$ as equilibration and elution buffer (Macedo et al. 1995).

Chemical analysis. Protein was determined by the dye binding method of Bradford (1976) or alternatively by the absorbance at $280 \mathrm{~nm}$. An ELISA assay employing an antibody produced against $P$. vulgaris phaseolin was used to quantify phaseolin in testa and embryo tissues.

The presence of phenols in testa and embryo tissues and their quantitation were determined by a procedure described by Chiang and Jackay (1988) that is based on the formation of color complexes between ferric ion and phenol. Tannins were determined by a procedure based on the complex formation between these compounds and proteins, which employs rabbit blood as the source of proteins (Chiang and Jackay 1988).

The presence of cyanide resulting from the hydrolysis of cyanogenic glycosides was measured by the method described by Esashi et al. (1991), which is based in the reaction of $\mathrm{HCN}$ with chloramine-T.

\section{Polyacrylamide gel electrophoresis and West-} ern blotting. SDS-PAGE was performed according to Laemmli (1970). Samples $(20 \mathrm{mug}$ ) were dissolved in $0.05 \mathrm{M}$ Tris, $12 \%$ glycerol, $4 \%$ SDS, $0.01 \%$ bromophenol blue, $2 \% \beta$-mercaptoethanol and heated for $3 \mathrm{~min}$ at $100^{\circ} \mathrm{C}$. Electrophoresis was run at $15 \mathrm{~mA}$ and gels were stained by $0.05 \%$ Coomassie Blue and de-stained in acetic acid. Following SDS-PAGE Western blotting was done using nitro-cellulose membranes according to Towbin et al. (1979).

$\mathbf{N}$-amino acid sequencing. $\mathrm{N}$-terminal amino acid sequences were performed on a Shimadzu PPSQ10 Automated Protein Sequencer performing Edman degradation. Sequences were determined from proteins blotted on PVDF membranes after SDS-PAGE. PTH-amino acids were detected at $269 \mathrm{~nm}$ after sep- aration on a reverse-phase $\mathrm{C} 18$ column $(4.6 \mathrm{~mm} \times$ $2.5 \mathrm{~mm}$ ) under isocratic conditions, according to the manufacturer's instructions. The sequences were compared to amino acid data banks. The sequences selected were submitted to automatic alignment, which was performed by using the NCBIBLAST search system.

\section{RESULTS}

The thickness of the testa of the seeds of $P$. vulgaris employed in this study (WAF-9 and "preto" genotypes) was $0.13 \pm 0.03 \mathrm{~mm}$ and of seeds of $V$. unguiculata (EPACE-10 and IT81D-1045 genotypes) was $0.11 \pm 0.03 \mathrm{~mm}$ and $0.12 \pm 0.02 \mathrm{~mm}$, respectively. Several components of the testa were measured in these and other seeds. Some of these compounds are thought to be detrimental to the development of insects and of C. maculatus in particular (Janzen 1977, Boughdad et al. 1986). Data in Table II show a high variability in the levels of all the components examined. The level of phenols (as tannic acid) in the testa of $V$. unguiculata (EPACE10 ) is more than 60 times that in P. vulgaris (WAF-9) while tannin varies only 2.6 times between the testa of these same seeds. The concentration of cyanide (as $\mathrm{HCN}$ ) varies 2 times between the lowest level (that in V. unguiculata, "fradinho") and the highest (in P. vulgaris, WAF-9). As for protein, the testa of $P$. vulgaris (WAF-9) shows the highest level while the level of vicilin (phaseolin) is higher than in the testa of $V$. unguiculata (EPACE-10).

We observed that a high proportion $(98.7 \pm$ 1.9 and $86.6 \pm 2.9 \%$, respectively) of $C$. maculatus eggs laid on $P$. vulgaris seeds ("preto" and WAF9 genotypes) hatch but do not give rise to adults. Furthermore, $62.1 \pm 5.0$ and $46.2 \pm 3.9 \%$ of the larvae die on the testa, respectively. All remaining larvae die during penetration of embryonic tissues.

The powdered testa tissues of $P$. vulgaris and $V$. unguiculata when incorporated in artificial seeds are highly detrimental to the larval development of C. maculatus (Table III and Fig. 1). We see that the powdered testa tissues of all the seeds examined 
TABLE I

Seed color and mass and testa thickness for some legume seeds.

\begin{tabular}{l|c|c|c}
\hline & Seed color & $\begin{array}{c}\text { Mass of one } \\
\text { seed }(\mathrm{g})\end{array}$ & $\begin{array}{c}\text { Testa thickness } \\
(\mathrm{mm})\end{array}$ \\
\hline P. vulgaris (WAF-9) & White & & $0.13 \pm 0.03$ \\
P. vulgaris "preto" & Black & & $0.13 \pm 0.03$ \\
V. unguiculata (EPACE-10) & Brown & $0.21 \pm 0.007$ & $0.11 \pm 0.03$ \\
V. unguiculata (IT81D-1045) & Dark brown & & $0.12 \pm 0.02$ \\
\hline
\end{tabular}

The values given are the average ( \pm sd) of twenty determinations.

TABLE II

Phenols, tannin, HCN, protein and phaseolin (or vicilin) contents (as percentage of the fresh weight) of testa tissue of Phaseolus vulgaris and Vigna unguiculata.

\begin{tabular}{|c|c|c|c|c|c|}
\hline Seed & $\begin{array}{l}\text { Phenols (tannic } \\
\text { acid elements) } \\
\text { (\% fresh weight) }\end{array}$ & $\begin{array}{c}\text { Tannin } \\
\text { (\% fresh weight) }\end{array}$ & $\begin{array}{c}\mathrm{HCN} \\
(\% \text { fresh weight })\end{array}$ & $\begin{array}{c}\text { Protein } \\
(\% \text { fresh weight })\end{array}$ & $\begin{array}{c}\text { Phaseolin } \\
\text { (or vicilin) } \\
\text { (\% fresh weight) }\end{array}$ \\
\hline $\begin{array}{l}\text { Phaseolus vulgaris, } \\
\text { WAF-9 (white testa) }\end{array}$ & $0.12 \pm 0.03^{\mathrm{a}}$ & $2.66 \pm 0.03^{\mathrm{a}}$ & $0.008 \pm 0.0005^{\mathrm{c}}$ & $5.33 \pm 0.62^{\mathrm{e}}$ & $3.54 \pm 0.35$ \\
\hline $\begin{array}{l}\text { Phaseolus vulgaris, } \\
\text { "preto", (black testa) }\end{array}$ & $3.73 \pm 0.11^{\mathrm{c}}$ & $3.34 \pm 0.02^{\mathrm{b}}$ & $0.006 \pm 0.0002^{\mathrm{b}}$ & $1.25 \pm 0.09^{\mathrm{b}}$ & nd \\
\hline $\begin{array}{l}\text { Vigna unguiculata, } \\
\text { IT81D-1045 (brown testa) }\end{array}$ & $4.88 \pm 0.12^{\mathrm{d}}$ & $5.21 \pm 0.10^{\mathrm{d}}$ & $0.008 \pm 0.0009^{c}$ & $1.93 \pm 0.27^{\mathrm{c}}$ & nd \\
\hline $\begin{array}{l}\text { Vigna unguiculata, } \\
\text { EPACE-10 (brown testa) }\end{array}$ & $7.44 \pm 0.24^{\mathrm{e}}$ & $6.79 \pm 0.04^{\mathrm{e}}$ & $0.006 \pm 0.0005^{\mathrm{b}}$ & $3.57 \pm 0.18^{\mathrm{d}}$ & $1.1 \pm 0.06$ \\
\hline $\begin{array}{l}\text { Vigna unguiculata, } \\
\text { "fradinho", (white testa) }\end{array}$ & $1.62 \pm 0.10^{\mathrm{b}}$ & $3.83 \pm 0.01^{\mathrm{c}}$ & $0.004 \pm 0.0003^{\mathrm{a}}$ & $0.98 \pm 0.10^{\mathrm{a}}$ & nd \\
\hline
\end{tabular}

Values are means $\pm \mathrm{sd}$ of three independent experiments. Values followed by the same letter in a column are not significantly different (Duncan's multiple range test, $\mathrm{P} \leq 0.05$ ). nd, not determined.

equally affect the development of this bruchid.

Vicilins (7S globulins or phaseolins) isolated from both embryo and testa tissues of $P$. vulgaris seeds were shown to be as detrimental to C. maculatus development as vicilin isolated from the embryo of resistant $V$. unguiculata seeds (Table IV).

Protein bands from $P$. vulgaris embryo and testa separated by PAGE-SDS and that react with antibody against $P$. vulgaris phaseolin are seen in Fig. 2. The protein bands of interest (I, II, III, IV, Fig. 2) were transferred to PVDF membranes and excised thereof and submitted to N-terminal amino acid sequencing. Sequences are shown in Fig. 3 with the accompanying sequence of the $\mathrm{N}$-terminal portion of a known phaseolin molecule [gi: 230247].

\section{DISCUSSION}

We have here confirmed previous observations that the seeds of $P$. vulgaris do not support the development of the bruchid C. maculatus (Applebaum et al. 1970). This has been explained by the action of toxic constituents present in these seed such as $\alpha$-amylase inhibitors and lectins contained in varying amounts in the embryo (cotyledons plus axes tissues). Most of the studies did not refer to the fact that larvae of the insect, after egg hatching, have to traverse the testa tissues in order to get to the rich cotyledon stores. We have shown here that most of 
TABLE III

Effect of the addition of testa flours of Phaseolus vulgaris and Vigna unguiculata seeds on the development of Callosobruchus maculatus.

\begin{tabular}{l|c|c|c}
\hline Species & $\begin{array}{c}\text { Effective dose } \\
{\left[\mathrm{ED}_{50}\right](\%)}\end{array}$ & $\begin{array}{c}\text { Lethal dose } \\
{\left[\mathrm{LD}_{50}\right](\%)}\end{array}$ & $\begin{array}{c}\text { Behavior in } \\
\text { intact seed }\end{array}$ \\
\hline Phaseolus vulgaris, WAF-9 & $0.5\left(^{*}\right)$ & 6.4 & Die in testa \\
Phaseolus vulgaris, "preto", (black testa) & $1.9(*)$ & 3.6 & Die in testa \\
Vigna unguiculata, IT81D-1045 & $2.3(*)$ & $2.8(*)$ & Die in embryo \\
Vigna unguiculata, EPACE-10 & 2.0 & 4.7 & Adults emerge \\
Vigna unguiculata, "fradinho" (white testa) & $1.3(*)$ & $2.6(*)$ & Adults emerge \\
\hline
\end{tabular}

Effective doses for $50 \%$ response $\left(\mathrm{ED}_{50}, \%\right)$ are the concentrations of protein fractions that decrease the mass of the larvae to $50 \%$ of the mass of the control. Lethal doses $\left(\mathrm{LD}_{50}, \%\right)$ are the concentrations of protein fractions that decrease the number of larvae to $50 \%$ of the number found in control seeds. The values were calculated from dose-response curves [values marked $(*)$ were computed from regression curves that showed $\mathrm{r}$ values with $\mathrm{P}<0.1$; all others $\mathrm{P}>0.01]$.

\section{TABLE IV}

Effective doses for $50 \%$ response $\left(\mathrm{ED}_{50} \pm\right.$ sd) for 20 -day larvae of Callosobruchus maculatus fed on artificial seeds containing vicilins isolated from legume seeds.

\begin{tabular}{l|c}
\hline Vicilin origin & {$\left[\mathrm{ED}_{50} \% \pm \mathrm{sd} \% \pm \mathrm{sd} \%\right.$} \\
\hline Embryo of Phaseolus vulgaris, WAF-9 & $2.22 \pm 0.64$ \\
Testa of Phaseolus vulgaris, WAF-9 & $0.84 \pm 0.10$ \\
Embryo of Vigna unguiculata (EPACE-10) & $6.3 *$ \\
Embryo of Vigna unguiculata (IT81D-1045) & $1.07 \pm 0.32 * *$ \\
\hline
\end{tabular}

Effective doses for $50 \%$ response $\left(\mathrm{ED}_{50}, \%\right)$ are the concentrations of protein fractions that decrease the mass of the larvae to $50 \%$ of the mass of the control. The values were calculated from dose-response curves. Values taken from Moraes et al. (2000) and values taken from Yunes et al. (1998).

the viable larvae $(62.1 \%$ to $46.2 \%$, depending on the bean genotype studied) die on the testa. All remaining larvae die during penetration of embryonic tissues, possibly as a result of ingesting the mix of its toxic components. These findings strongly suggest that the testa is an important barrier to the infestation of $P$. vulgaris seeds by $C$. maculatus and is in line with our previous reports on its role in the discrimination of the seeds of the legumes $P$. lunatus and C. ensiformis by this bruchid (Oliveira et al. 1999,
Moraes et al. 2000).

It is worth noting that the thickness of the testa of the seeds of both the $P$. vulgaris genotypes utilized by us $(0.13 \mathrm{~mm} \pm 0.03)$ is of the same order as that of the testa of $C$. maculatus-resistant and -susceptible $V$. unguiculata seeds $(0.11 \mathrm{~mm} \pm 0.03$ and $0.12 \mathrm{~mm} \pm 0.02)$. We assume then that testa thickness is not a factor that is important in the resistance of these seeds to C. maculatus as already suggested by Seifelnasr (1991). 

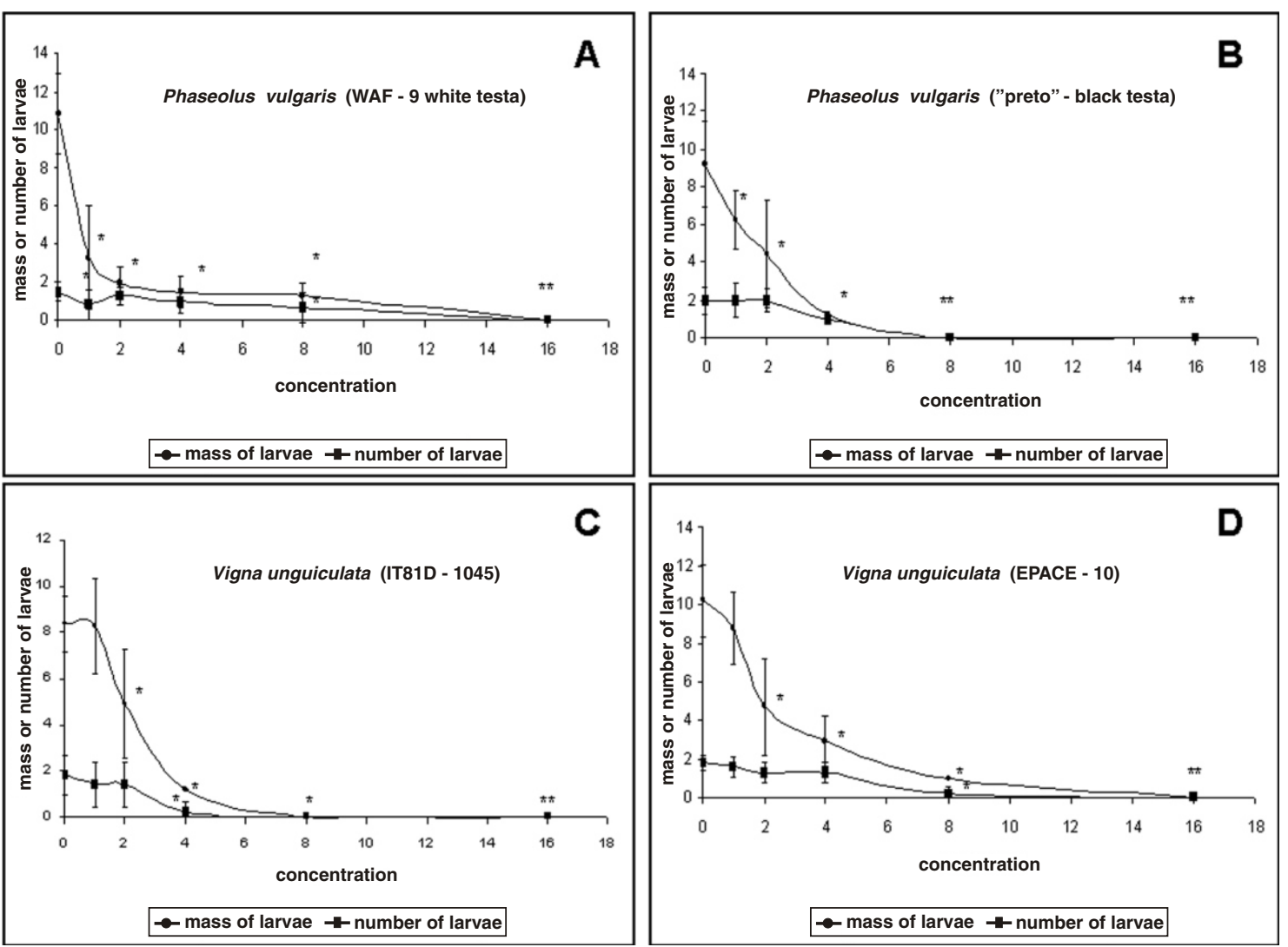

Fig. 1 - Effect of ground testa tissues of Phaseolus vulgaris and Vigna unguiculata seeds on Callosobruchus maculatus larval development weight and survival after 20 days. Powdered testa of the several seeds [(A) P. vulgaris (WAF-9); (B) P. vulgaris “preto" black testa; (C) V. unguiculata (EPACE-10); (D) V. unguiculata (IT81D-1045)] were incorporated into artificial seeds in different concentrations (1.0, 2.0, 4.0, 8.0 and 16.0\%). Error bars represent independent SEM (*indicates values significantly different, $\mathrm{p} \leq 0,05)$.

To examine the presence of factors possibly detrimental to C. maculatus development in the testa of $P$. vulgaris we first incorporated finely ground testa tissues in artificial seeds (Macedo et al. 1993) and supplied these to ovipositing females. The results suggest that the testa tissues of the examined seeds do not support development of the bruchid even in those seeds ( $V$. unguiculata) that are host to the insect (Table II and Fig. 1). We suggest that the testa of both P. vulgaris and V. unguiculata seeds contain detrimental factors to C. $\mathrm{macu}$ latus but in the case of cowpea, intact tissues allow crossing of this barrier without the insect being affected. We have previously noticed that aque- ous buffer-insoluble materials from the testa of both $C$. ensiformis and P. lunatus are detrimental do $C$. maculatus development and survival (Oliveira et al. 1999, Moraes et al. 2000). These results and those reported here suggest that many insoluble components present in high levels in the testa could be responsible for these effects (Bewley and Black 1994).

Screening of buffer-soluble components of the testa suggests that there is no correlation between the levels of phenols, tannins, $\mathrm{HCN}$, and protein and the development and survival of $C$. maculatus (Tables I and III). This finding is in accord with our suggestion that there is also no correlation between the levels of these same components in the testa of $C$. ensiformis 


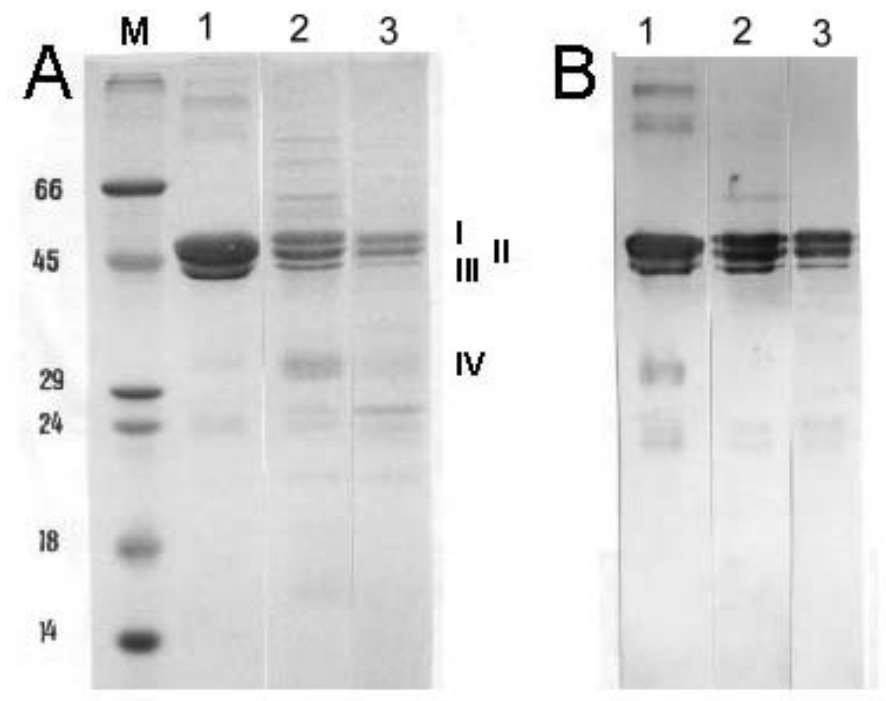

Fig. 2 - SDS polycarylamide gel electrophoresis and Western blotting of proteins from Phaseolus vulgaris seeds. (A) Coomassie blue staining (protein) and (B) Western blotting employing an antiserum against phaseolin. (1) purified phaseolin from embryo; (2) total extracted proteins from embryo; (3) total extracted protein from testa; (M) molecular markers, $\mathrm{kDa} \times 10^{3}$.

\begin{tabular}{|c|c|c|c|c|c|c|c|c|c|c|c|c|c|c|c|c|c|c|c|c|}
\hline P. vulgaris testa band I & & & & & $\mathrm{S}$ & $\mathrm{L}$ & $\mathrm{S}$ & $\mathrm{G}$ & $\mathrm{S}$ & $\mathrm{E}$ & $\mathrm{X}$ & $\mathrm{S}$ & Q & $\mathrm{D}$ & $\mathrm{N}$ & $\mathrm{P}$ & $\mathrm{F}$ & $\mathrm{Y}$ & $\mathrm{N}$ & $\mathrm{S}$ \\
\hline P. vulgaris testa band II & & & & $X$ & $\mathrm{X}$ & $\mathrm{L}$ & $\mathrm{E}$ & $\mathrm{E}$ & $\mathrm{E}$ & $\mathrm{X}$ & $\mathrm{X}$ & $\mathrm{S}$ & $\mathrm{Q}$ & $\mathrm{D}$ & $\mathrm{N}$ & $\mathrm{P}$ & $\mathrm{F}$ & $\mathrm{Y}$ & $\mathrm{N}$ & $\mathrm{S}$ \\
\hline P. vulgaris testa band III & & & & & $\mathrm{S}$ & $\mathrm{L}$ & $\mathrm{E}$ & $\mathrm{E}$ & $\mathrm{E}$ & $\mathrm{X}$ & $\mathrm{X}$ & $\mathrm{S}$ & Q & $\mathrm{D}$ & $\mathrm{N}$ & $\mathrm{P}$ & $\mathrm{F}$ & $\mathrm{Y}$ & $\mathrm{N}$ & $\mathrm{S}$ \\
\hline P. vulgaris testa band IV & & & & $\mathrm{X}$ & $\mathrm{Q}$ & $\mathrm{L}$ & $\mathrm{R}$ & $\mathrm{E}$ & $\mathrm{E}$ & $\mathrm{E}$ & $\mathrm{X}$ & $\mathrm{S}$ & Q & $\mathrm{D}$ & $\mathrm{N}$ & $\mathrm{P}$ & $\mathrm{F}$ & & & \\
\hline $\begin{array}{l}\text { P. vulgaris phaseolin } \\
\text { [gi: 230247] }\end{array}$ & 1 & $\mathrm{~T}$ & $\mathrm{~S}$ & $\mathrm{~L}$ & $\mathrm{R}$ & $\mathrm{E}$ & $\mathrm{E}$ & $\mathrm{E}$ & $\mathrm{E}$ & $\mathrm{S}$ & Q & $\mathrm{D}$ & $\mathrm{N}$ & $\mathrm{P}$ & $\mathrm{F}$ & $\mathrm{Y}$ & $\mathrm{N}$ & $\mathrm{S}$ & & \\
\hline
\end{tabular}

Fig. 3 - N-terminal amino acid sequences of peptides isolated (by SDS-PAGE) from the testa of Phaseolus vulgaris. The sequences of protein bands I-IV were compared with the sequence of phaseolin [gi:230247].

and $P$. lunatus and development or survival of this bruchid (Oliveira et al. 1999, Moraes et al. 2000).

Vicilins (or phaseolin) isolated from C. maculatus-resistant cowpea and P. vulgaris seeds were shown to be detrimental to the development of this insect (Yunes et al. 1998). Their presence in the testa of legume seeds (e.g. C. ensiformis and $P$. lunatus) may explain their resistance to the bruchid (Oliveira et al. 1999, Moraes et al. 2000). When we examined (by an ELISA assay) the levels of phaseolin in the testa of P. vulgaris (WAF 9) we found a value more than $3 \times(3.54 \div 1.1)$ that for vicilin from the $C$. maculatus-susceptible $V$. unguiculata (EPACE-10 genotype) (Table I). Considering that phaseolin from common bean seeds is detrimental to the bruchid (Yunes et al. 1998 and Table III) the high level found in the testa of P. vulgaris (WAF 9) could explain, at least in part, the effects exerted by the testa of this seed on C. maculatus development.

In order to show that some of the proteins found in the testa tissues of P. vulgaris WAF 9 (Fig. 2) are indeed phaseolins (vicilins) we submitted proteins separated by SDS-PAGE to N-terminal amino acid sequencing. The four protein bands (Fig. 3) exam- 
ined show N-terminal sequences with a high degree of homology to a phaseolin isolated from the embryo.

We are then led to conclude that, as is the case with the legumes $C$. ensiformis and $P$. lunatus, the testa of $P$. vulgaris may have been one of the factors which were important in the evolutionary discrimination of these seeds by bruchids (Janzen 1977, Jermy 1984, Oliveira et al. 1999, Moraes et al. 2000).

\section{ACKNOWLEDGMENTS}

This work was supported by grants from the Brazilian agencies Coordenação de Aperfeiçoamento de Pessoal de Nível Superior, Conselho Nacional de Desenvolvimento Científico e Tecnológico, Financiadora de Estudos e Projetos, Programa de Apoio a Núcleos de Excelência, and from the Universidade Estadual do Norte Fluminense supporting body Fundação Estadual do Norte Fluminense.

\section{RESUMO}

Neste trabalho confirmamos a resistência do feijão comum (Phaseolus vulgaris) ao bruquídeo Callosobruchus maculatus (F.), inseto que preda sementes de feijão-de-corda (Vigna unguiculata) (L.). A resistência desta semente não está relacionada com a espessura do tegumento nem com os níveis de diversos compostos como ácido taníco, fenóis e ácido cianídrico conforme demonstram nossos resultados. No entanto, faseolina, detectada no tegumento por “Western blotting", e seqüenciamento N-terminal, é tóxica a C. maculatus. Esses dados estão de acordo com estudos anteriores feitos com duas outras sementes de leguminosas (Canavalia ensiformis e Phaseolus lunatus) e nos levam a sugerir que a presença de proteínas do tipo vicilina no tegumento de sementes de leguminosas tiveram papel importante nos mecanismo de adaptação de bruquídeos a sementes de leguminosas.

Palavras-chave: feijão comum, phaseolina (vicilina), tegumento, resistência, carundho do feijão-de-corda.

\section{REFERENCES}

Applebaum SW, Tadmore U and Podoler M. 1970. The effect of starch and of a heteropolysaccharide fraction from Phaseolus vulgaris on development and fecundity of Callosobruchus maculatus (F.). Entomol Exp Appl 13: 61-70.

Bewley JD ANd Black M. 1994. Seeds: Physiology of Development and Germination, 2nd ed. Plenum Press, New York, p 44-50.

Boughdad AA, Gillon Y and Gagnepain C. 1986. Influence du tégument des graines mûres de Vicia faba sur le développement larvaire de Callosobruchus maculatus. Entomol Exp Appl 42: 219-223.

BRADFORD MM. 1976. A rapid and sensitive method for the quantitation of microgram quantities of protein utilizing the principle of protein-dye binding. Anal Biochem 72: 248-254.

Chiang HS And JaCKay LEN. 1988. Tough pod wall: A factor involved in cowpea resistance to pod sucking bugs. Insect Sci 9: 389-393.

Esashi Y, Isuzugawa K, Matsuyama S, Ashino H AND Hasegawa R. 1991. Endogenous evolution of hen during pre-germination periods in many seed species.Physiol Plant 83: 27-33.

JANZEN D. 1977. How Southern cowpea weevil larvae (Bruchidae: Callosobruchus maculatus) die on nonhost seeds. Ecology 58: 921-927.

JERMY T. 1984. Evolution of insect/host plant relationships. Amer Natural 124: 609-630.

LAEMMLi KA. 1970. Cleavage of structural protein during assembly of head of bacteriophage T4. Nature 227: 680-685

Macedo MRL, Andrade LBS, Moraes RA AND XAVIER-FILHO J. 1993. Vicilin variants and the resistance of cowpea (Vigna unguiculata) seeds to the cowpea weevil (Callosobruchus maculatus). Comp Biochem Physiol 105C: 89-94.

Macedo MRL, Fernandes KVS, Sales MP AND Xavier-Filho J. 1995. Purification and properties of storage proteins (vicilins) from cowpea (Vigna unguiculata) seeds which are susceptible or resistant to the bruchid beetle. Braz J Med Biol Res 28: 183-190.

Moraes RA, Sales MP, Silva LB, Oliveira AEA, Machado OLT, Fernandes KVS and XavierFilho J. 2000. Phaseolin in Phaseolus lunatus testa 
is detrimental to Callosobruchus maculatus (cowpea weevil). Braz J Med Biol Res 33: 191-198.

Oliveira AEA, Sales MP, Machado OLT, Fernandes KVS AND Xavier-Filho J. 1999. The toxicity of the jack bean [Canavalia ensiformis (L.) DC] cotyledonary and testa proteins to the cowpea weevil [Callosobruchus maculatus (F)]. Entomol Exp Appl 92: 249-255.

Sales MP, Gerhardt IR, Grossi-DE-SÁ MF AND Xavier-Filho J. 2000. Do Legume Storage Proteins Play a Role in Defending Seeds Against Bruchids? Plant Physiol. 124: 515-522.

Schoonhoven AV, Cardona C and Valor J. 1983. Resistance to the bean weevil and the Mexican bean weevil (Coleoptera: Bruchidae) in noncultivated common bean accessions. J Econ Entomol 76: 1255-1259.
SEIFELNASR YE. 1991. The role of asparagine and seed coat thickness in resistance of Phaseolus vulgaris (L.) to Callosobruchus maculatus (F.) (Col., Bruchidae). J Appl Entomol 111: 412-417.

SmartT J. 1990. Grain Legumes - Evolution and Genetic Resources, Cambridge University Press, Cambridge, MA.

Towbin H, Stachelin NT AND Gordon J. 1979. Electrophoretic transfer of proteins from polyacrylamide gels to nitrocellulose sheets; procedures and some applications. Proc Nat Acad Sci USA 176: 4350-4354.

Yunes ANA, Andrade MT, Sales MP, Morais RA, FERnANDES KVS AND XAVIER-Filho J. 1998. Legume seed vicilins (7S storage proteins) interfere with the development of the cowpea weevil [Callosobruchus maculatus (F.)]. J Sci Food Agric 76: 111-116. 